\title{
Důraz školy na akademický úspěch: TIMSS 2011 jako sonda do reformy v České republice ${ }^{1}$
}

\author{
Dominik Dvořák \\ Univerzita Karlova v Praze, Pedagogická fakulta, Ústav výzkumu a rozvoje vzdělávání
}

Redakci zasláno 26. 2. 2015 / upravená verze obdržena 15. 6. 2015 /

k uveřejnění přijato 16. 6. 2015

\begin{abstract}
Abstrakt: V šetření TIMSS 2011 se objevil index nazvaný „důraz školy na studijní úspěch“ (SEAS). Cílem článku je osvětlit skutečnost, že české školy vykazují poměrně nápadné hodnoty tohoto indexu. Dále pomocí SEAS analyzuje vztah mezi postoji českých škol k reformě a znalostmi a dovednostmi jejich žáků. Teoretický úvod popisuje konstrukt akademický optimismus a index SEAS zavedený v šetření TIMSS. Následně je provedena explorativní sekundární analýza dat o úrovni složek SEAS v případě českých škol se zaměřením na nápadné odchylky hodnot. Práce vychází z výsledků žáků čtvrtých ročníků v matematickém testu TIMSS 2011 a z odpovídajících učitelských a ředitelských dotazníků. Pro analýzu vztahů v datech jsou použity základní prostředky popisné a inferenční statistiky. Zjištění ukazují na disproporčně nízkou důvěru ředitelů ve snahu žáků ve škole dobře prospívat, která je společná regionálnímu klastru zemí. Dále analýza přinesla nečekaná zjištění o vztahu mezi postoji ředitelů a učitelů ke kurikulární reformě a výsledky jejich žáků v matematice. Z literatury známá i naše původní zjištění o komponentách indexu SEAS v podmínkách českých škol přinášejí zajímavé pohledy mj. na vnímání reformních procesů v českých školách a doplňují tak literaturu o implementaci, resp. recepci reformy.
\end{abstract}

Klíčová slova: důraz školy na studijní úspěch, akademický optimismus, kurikulární reforma, Česká republika, TIMSS 2011

Panuje široká shoda o tom, že globálním trendem ve vzdělávání se stalo zaměření na výsledky učení. Stále více zemí měří kognitivní výkony svých žáků (Eurydice, 2009; UNESCO, 2007). Odpovídající vzdělávací politiky při tom deklarují význam osvojení nadpředmětových kompetencí, avšak současně se klade důraz na dosažení vysoké úrovně základních gramotností/ dovedností, které korespondují s tradičními školními předměty (čtení, psaní,

1 Článek je výstupem projektu GA ČR: Vztahy mezi dovednostmi, vzděláváním a výsledky na trhu práce: longitudinální studie (P402/12/G130).

DOI: $10.5817 /$ PedOr2015-4-583 
matematika, případně přírodní vědy). $V$ hodnocení trendu $\mathrm{k}$ většímu využívání testů se ovšem různí autoři velmi liší (Bellmann \& Weiß, 2009; Bruns, Filmer, \& Petrinos, 2011; de Wolf \& Janssens, 2007; Sahlberg, 2011).

Za důležitou příčinu národních politik orientovaných na zlepšování měřitelných výsledků jsou považována mezinárodní šetření vzdělávacích výsledků. Rostoucí zájem politiků i části odborníků o srovnávání kognitivních cílů vzdělávání zpětně ovlivňuje podobu a vývoj těchto šetření. V šetření TIMSS 2011 se tak nově objevil index school emphasis on academic success (SEAS). V české národní zprávě je označen důraz školy na studijní úspěch (Tomášek, Kramplová, \& Palečková, 2012, s. 26). V tomto textu poukazuji na skutečnost, že Česká republika opakovaně vykazuje extrémně nízkou hodnotu v jednom z aspektů tvořících SEAS, a diskutuji možné příčiny netypického vztahu mezi tímto konstruktem a výsledky vzdělávání u nás. V neposlední řadě upozorňuji, že dotazníky TIMSS mohou poskytnout dosud málo využitý pohled na českou kurikulární reformu. Vzhledem k tomu, že Česká republika v šetření TIMSS 2011 sledovala pouze žáky čtvrtých ročníků, budu v celém textu mít na mysli tuto věkovou skupinu, resp. odpovídající stupeň školy.

\section{Akademické/studijní cíle a celoškolní faktory jejich dosahování}

Anglická pedagogická terminologie běžně užívá adjektivum academic jako neutrální označení některých cílů základního (včetně primárního) vzdělávání. $V$ češtině není jeho překlad $v$ tomto významu ustálen. ${ }^{2}$ Jako přijatelné se jeví řešení zvolené Tomáškem a kol. (2012, s. 26), kdy pro academic success je použit studijní úspěch. $V$ tomto textu budu používat termíny studijní a akademický jako vzájemně zaměnitelné. Vesměs se jinak všude držím terminologie užívané v našich národních zprávách TIMSS.

V mezinárodní vědecké komunitě panuje relativně široká pragmatická shoda na dobře operacionalizovaných a měřitelných akademických cílech všeobecného vzdělávání. ${ }^{3}$ To vytváří paradigmatický rámec, v němž se pak

2 Absence určitého termínu v češtině může naznačovat absenci (potřeby) příslušného pojmu v našem odborném diskurzu.

3 Odpovídají zhruba triviu nebo tomu, co u žáků zjištujuí šetření TIMSS a PIRLS - porozumění textu, používání a aplikování matematických a přírodovědných znalostí a dovedností, uvažování o problémech, případně postoje k odpovídajícím předmětům. V podmínkách malých národů musíme ještě předpokládat angličtinu i další cizí jazyky. Nad rámec toho, co př́mo sleduje TIMSS a PIRLS, $\mathrm{k}$ akademickým cílům dále patří zejména psaní. 
může rozvíjet „normální“ (v kuhnovském smyslu) věda, hledající výzkumem podložené cesty k efektivnímu dosahování těchto cílů. Jedna linie tohoto výzkumu zkoumá vlastnosti žáka, které přispívají k jeho studijnímu úspěchu, a zaměřuje se na konstrukty jako akademické sebepojetí (Marsh et al., 2005), v českém prostředí označované také školní sebepojetí (ČŠI, 2013). My se však budeme zabývat charakteristikami akademicky úspěšných škol (Creemers \& Kyriakides, 2008; Hopkins et al., 2014). Zde se dlouhodobě studuje otázka, zda vůbec existují prakticky významné efekty školy na výsledky žáků, zejména s ohledem na možnost školy přispívat k snížení závislosti výsledků na socioekonomickém původu žáka (zvyšování spravedlivosti vzdělávání). Dnes převládá názor, že efekty školy existují a jsou vyšší právě u kognitivních akademických výsledků (typicky v matematice) než v oblasti afektivních cílů (Reynolds et al., 2014).

\subsection{Akademický optimismus a koncept SEAS}

Různé výzkumy efektivních škol dlouhodobě docházejí k obdobným faktorům jejich úspěšnosti, jako jsou vyjadřovaná vysoká očekávání směrem k žákům, časté hodnocení (měření) výsledků žáků, bezpečné a ukázněné prostředí nebo dobré vztahy mezi školou a rodinou (Marzano, 2003; Marzano, Waters, \& McNulty, 2005; Redding, 2006). Specifický př́ístup v rámci těchto analýz rozvinul v uplynulých dekádách Hoy (2012). Na počátku jeho práce stálo empirické zjištění, že neexistuje souvislost mezi klimatem školy a studijními výsledky žáků. Zaměřil se proto postupně na tři jiné faktory (tabulka 1), jež charakterizují působení školy jako celku a systematicky predikují schopnost školy pozitivně ovlivňovat akademické výsledky žáků bez ohledu na jejich rodinné zázemí.

Tabulka 1

Faktory tvořící akademický optimismus

\begin{tabular}{ll}
\hline Faktor & Vymezení \\
\hline $\begin{array}{l}\text { studijní důraz (academic } \\
\text { emphasis) }\end{array}$ & $\begin{array}{l}\text { škola je vedena úsilím o akademickou excelenci - vyvíjí tlak } \\
\text { na akademický prospěch }\end{array}$ \\
$\begin{array}{l}\text { vnímaná kolektivní zdatnost } \\
\text { (perceived collective teacher } \\
\text { efficacy) }\end{array}$ & $\begin{array}{l}\text { přesvědčení (učitelů), že sbor jako celek dokáže naplánovat } \\
\text { důvěra v žáky a jejich rodiče } \\
\text { (trust) }\end{array}$ \\
$\begin{array}{l}\text { ochota vystavit se ohrožení jiným založená na víre, že onen } \\
\text { jiný má dobré úmysly, je spolehlivý, kompetentní, uprímný } \\
\text { a otevřený }\end{array}$ \\
\hline
\end{tabular}

Pozn. Převzato z Hoy, Tarter, \& W. Hoy (2006). 
Hoyův přístup odpovídá duchu pozitivní psychologie v tom, že jde o kolektivní (celoškolní) fenomény ${ }^{4}$ zdůrazňující význam sociálních faktorů či interakcí mezi lidmi (Křivohlavý, 2004; Mareš, 2001; Shulman \& Sherin, 2004), $\mathrm{v}$ tomto případě jednak mezi učiteli ve škole navzájem, jednak mezi učiteli a ostatními aktéry. Např́íklad první faktor zohledňuje jak chování učitelů školy (jaké cíle předkládají žákům), tak i postoje a chování žáků (kázeň, motivaci, úctu $\mathrm{k}$ dobrému prospěchu). Ve druhém faktoru rozpoznáme Bandurův koncept vnímané zdatnosti (Gavora, 2008) - vyjadřuje přesvědčení učitelů, že když vynaloží úsilí, má to na žáky příznivý dopad. Třetí faktor důvěry je převážně afektivní, přitom důvěra k žákům a rodičům se na úrovni základní školy obvykle jeví jako jeden faktor (Hoy, 2012, s. 82), takže se mluví o důvěře ke klientům. Tyto tři faktory jsou dále vzájemně korelované a společně vytvářejí ve škole př́íznivé podmínky, jež Hoy (2012) charakterizuje konstruktem akademického optimismu. Vyjadřuje, že učitelé věří sobě i svým klientům, resp. žákům (kteří se mohou a chtějí učit), tato pozitivní energie se projevuje v jednání aktérů a nalézá svůj cíl v akademických cílech. Hoyưv akademický optimismus (podobně jako index SEAS) připomíná ještě jiný koncept pozitivní psychologie, totiž naději (Křivohlavý, 2004), kdy akademický optimismus můžeme chápat jako souhru cílů (kurikulum), cest k jejich realizaci (implementace), energie investované učiteli a žáky a konečně podpory z okolí (od rodičů).

Na Hoyovy práce navázalo šetření TIMSS 2011, které z otázek uvedených v tabulce 2 vytvořilo výše zmíněnou škálu důrazu školy na studijní úspěch - SEAS (Mullis et al., 2012, s. 248). ${ }^{5}$ Také konstrukt SEAS zajímavě kombinuje vnímání příspěvku učitelů, žáků a rodičů k studijnímu klimatu školy. Struktura

4 V poslední době se objevují práce i o individuálním akademickém optimismu učitelů a žáků.

5 V letech 2003 a 2007 byl v šetření TIMSS používán konstrukt ředitelovo vnímání školního klimatu (principals' perception of school climate, PPSC), do kterého bylo pod jinými názvy, ale ve stejné formulaci zahrnuto všech pět otázek, které v roce 2011 vstupují do SEAS. Naše neúčast v šetření 2003 se jeví jako nenahraditelná ztráta, nebot' jsme přišli o možnost znát úroveň těchto ukazatelů před začátkem reformy. V roce 2007 se žáci sice ještě neučili podle nového vzdělávacího programu, ale nelze pochybovat, že manifestní postoje ředitelů již byly probíhající reformou ovlivněny. V roce 2007 se pro Českou republiku ze všech zemí uváděl ve vztahu $\mathrm{k}$ 4. ročníkům vůbec nejmenší podíl žáků, v jejichž školách byl index PPSC vysoký (pouhé $1 \%$ žáků). Nejvyšší podíly žáků v této kategorii měl Tchaj-wan, anglosaské země (Austrálie, Nový Zéland, Skotsko, Anglie a USA) a s odstupem i Rakousko. Naopak podíl českých žáků ve školách s nízkou hodnotou indexu klimatu (21\%) patřil k vysokým, vyšší mělo jen Slovensko (27\%) a několik postsovětských a rozvíjejících se zemí. Také podíl českých žáků osmých ročníků ve školách s nízkou hodnotou indexu PPSC byl velmi vysoký (40\%), vyšší hodnotu uvádělo pouze Tunisko (Mullis et al., 2008, s. 355-361). 
SEAS je analogická akademickému optimismu: moment studijního důrazu školy je zde vyjádřen jako očekávání učitelů ohledně výsledků žáků; vnímaná kolektivní zdatnost učitelů koresponduje s pochopením cílů školního vzdělávacího programu ze strany učitelů a s vnímanou úspěšností (ostatních kolegů) při jeho realizaci; důvěra učitelů znamená přesvědčení o ochotě rodičů a žáků usilovat o dobrý prospěch. Konkrétním zněním českých položek se zabývám dále.

Tabulka 2

Různé jazykové verze položek odpovídajících aspektům SEAS ve školním dotazníku TIMSS

\begin{tabular}{|c|c|c|}
\hline česká & slovenská & mezinárodní \\
\hline $\begin{array}{l}\text { nároky učitelů na výsledky } \\
\text { žáků }\end{array}$ & $\begin{array}{l}\text { očakávania učitel’ov týkajúce } \\
\text { sa výsledkov žiakov }\end{array}$ & $\begin{array}{l}\text { teachers' expectations for } \\
\text { student achievement }\end{array}$ \\
\hline $\begin{array}{l}\text { pochopení cílů školního } \\
\text { vzdělávacího programu ze } \\
\text { strany učitelů }\end{array}$ & $\begin{array}{l}\text { miera pochopenia } \\
\text { vzdelávacích cielov školy } \\
\text { učitel'mi }\end{array}$ & $\begin{array}{l}\text { teachers' understanding of the } \\
\text { school's curricular goals }\end{array}$ \\
\hline $\begin{array}{l}\text { úspěšnost učitelů při realizaci } \\
\text { školního vzdělávacího } \\
\text { programu }\end{array}$ & $\begin{array}{l}\text { úspešnost' učitelov pri } \\
\text { realizácii učebných osnov }\end{array}$ & $\begin{array}{l}\text { teachers' degree of success } \\
\text { in implementing the school's } \\
\text { curriculum }\end{array}$ \\
\hline $\begin{array}{l}\text { zájem rodičů na dobrých } \\
\text { výsledcích žáků }\end{array}$ & $\begin{array}{l}\text { podpora rodičov pri učení } \\
\text { sa žiakov }\end{array}$ & $\begin{array}{l}\text { parental support for student } \\
\text { achievement }\end{array}$ \\
\hline $\begin{array}{l}\text { snaha žáků dobře ve škole } \\
\text { prospívat }\end{array}$ & $\begin{array}{l}\text { snaha žiakov dosahovat' } \\
\text { v škole dobré výsledky }\end{array}$ & students' desire to do well \\
\hline
\end{tabular}

\subsection{Výzkumný problém}

Z výsledků mezinárodních šetření obvykle budí největší zájem žebříčky zemí sestavené na základě průměrných skórů v kognitivních testech. $V$ jejich stínu zůstávají mnohá zjištění ze školních dotazníků, např. o nízké hodnotě indexu SEAS v českých školách (Tomášek et al., 2012, s. 26-27). Proto nejprve stručně připomenu některá zjištění z již publikovaných dat.

V obrázku 1 jsou vyznačeny evropské a kavkazské země, kde se žáci 4. ročníku účastnili šetření TIMSS 2011. Vodorovná osa uvádí podíl žáků, kteří se v dané zemi vzdělávají ve školách s vysokým nebo velmi vysokým SEAS (dle výpovědi ředitelů), svislá osa pro srovnání národní skór žáků čtvrtého ročníku v matematice. Ukazuje se, že ve všech západoevropských a většině východoevropských zemí je více žáků ve školách s vysokým nebo velmi vysokým SEAS než u nás. Velmi podobnou hodnotu jako Česká republika vykazují 
Slovensko a Madarsko. Pouze $1 \%$ českých žáků navštěvuje školy, kde jejich ředitelé hodnotí úroveň SEAS jako velmi vysokou. Z dalších účastníků výzkumu vykazují nižší SEAS ještě Turecko, Maroko, Tunisko nebo Chile. V grafu je naznačena i přímka popisující lineární vztah mezi celkovým průměrným skórem žáků čtvrtého ročníku v matematice a indexem SEAS v dané zemi (Pearsonův korelační koeficient je 0,45 ). Pokud bychom index SEAS konstruovali z výpovědí učitelů, dostali bychom v podstatě stejný obraz.

TIMSS je zaměřen na míru zvládání dovedností korespondujících s tradičními předměty školního kurikula. Proto by nemělo překvapit, že nejvyšší míru SEAS a také nejvyšší skór matematických dovedností v šetření TIMSS vykazují Severní Irsko a Anglie (spolu s Irskou republikou), kde základní dovednosti (literacy, numeracy) byly v posledních dekádách v popředí pozornosti a dostávalo se jim systematické péče prostřednictvím tzv. národních strategií, které jsou považovány za poměrně úspěšné reformy.

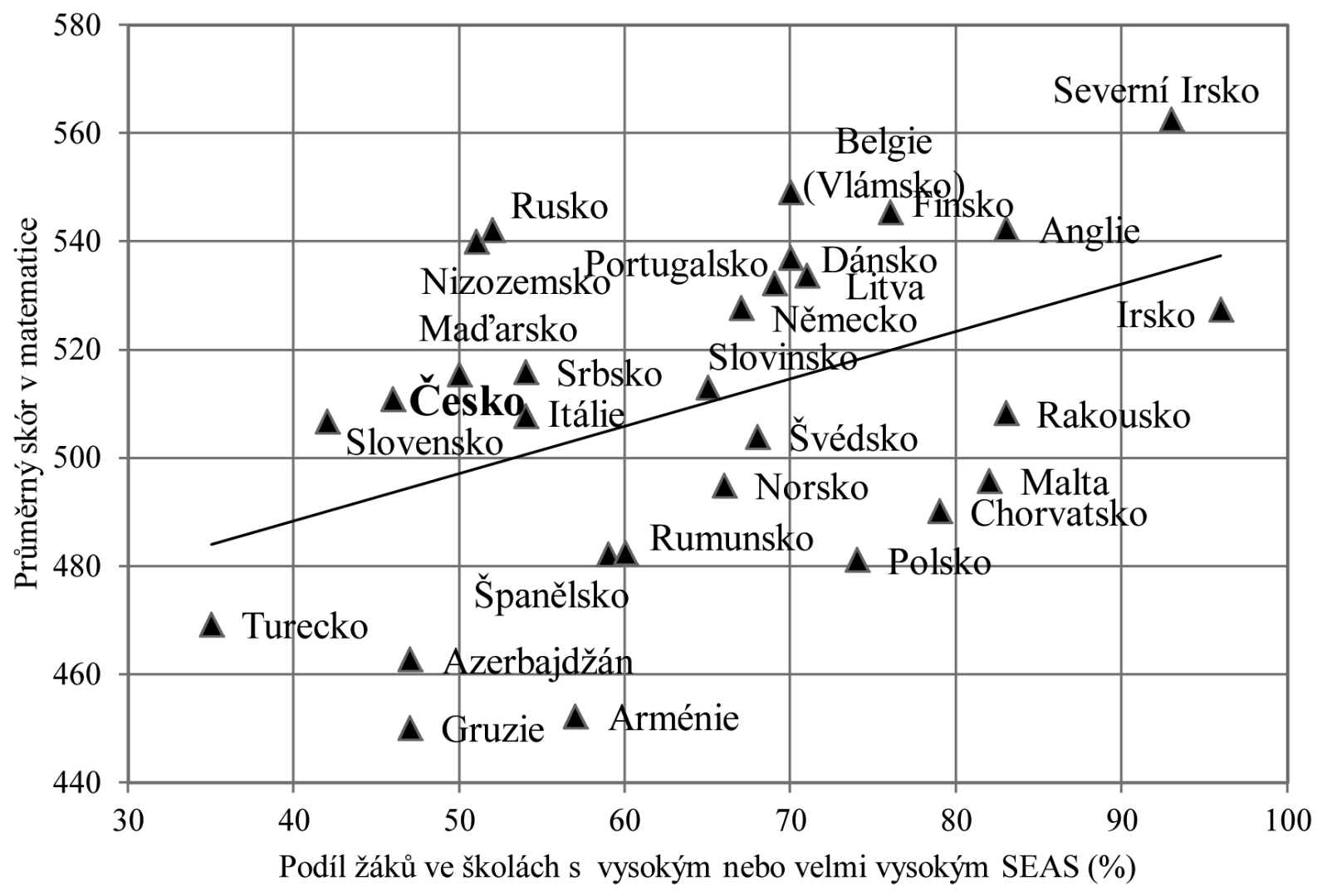

Obrázek 1. Vztah mezi SEAS a průměrným výsledkem v matematice na úrovni států v šetření TIMSS 2011. 
Podle našeho názoru představuje nízký SEAS v České republice jak výzkumný, tak praktický problém. Index SEAS je totiž obecně, podobně jako akademický optimismus, významným faktorem vysvětlujícím v šetření TIMSS v mnoha zemích rozdíly výsledků mezi školami vzdělávajícími žáky s podobným socioekonomickým zázemím. Nilsenová a Gustafsson (2014) se zase zabývali významnou pozitivní změnou výsledků norských žáků v čase v šetření TIMSS a ukázali, že celé zlepšení lze vysvětlit právě vzrůstem SEAS.

Martin a kol. (2013, s. 126) sledovali prostřednictvím víceúrovňového regresního modelu vliv kontextových indexů charakterizujících podmínky školy na výsledky žáků: SEAS má z pěti sledovaných škál nejvyšší vliv, další $\mathrm{v}$ pořadí byl index sledující bezpečnost a kázeň školního prostředí a index materiálních podmínek pro výuku. Tento vliv v řadě zemí přetrvává i po zohlednění socioekonomického zázemí žáků. Pouze ve dvou zemích - v České republice a Rusku - již v původním modelu (bez zohlednění rodinného původu žáků) žádný ze sledovaných faktorů nemá vliv na rozdíly ve výsledcích žáků, tedy ani SEAS. I když v tomto článku nenajdeme vysvětlení právě uvedeného zjištění, chceme přispět k lepšímu vhledu do problému indexu SEAS a jeho jednotlivých aspektů.

\section{Metoda}

V textu vycházíme z výsledků šetření TIMSS 2011, jehož cílem bylo především porovnat znalosti a dovednosti žáků z jednotlivých zemí. Tomu je také podřízena konstrukce národních vzorků. V České republice ho tvořilo 177 základních škol, více než 4500 žáků jejich čtvrtých ročníků a téměř pět set ředitelů a učitelů (Tomášek et al., 2012). Vzorek je dvoustupňový, nejprve jsou vybrány školy, $v$ jejich rámci pak celé třídy. Vedlejším přínosem tohoto postupu je možnost provádění víceúrovňových analýz. Při výběru škol je však hlavním cílem především reprezentativnost na úrovni výsledného žákovského vzorku, nikoli z hlediska proporčního zastoupení různých základních škol jako organizací (Rutkowski, von Davier, \& Rutkowski, 2013, s. 123). Přesto přináší mezinárodní šetření v našich podmínkách jedinečnou možnost propojit kolektivní charakteristiky škol a výsledky jejich žáků.

V rámci otázek na klima školy se respondenti vyjadřovali mj. k pěti aspektům, které jsou uvedeny v tabulce 2, měli při tom $\mathrm{k}$ dispozici pětibodovou škálu (1 - velmi vysoká, 2 - vysoká, 3 - střední, 4 - nízká, 5 - velmi nízká), na níž hodnotili úroveň daného aspektu. Mezinárodní zpráva uvádí, že obecně byli 
ředitelé velmi optimističtí, a proto byly školy rozděleny pouze do tří úrovní s velmi vysokou, vysokou a střední úrovní SEAS (Mullis et al., 2012, s. 249). Podrobnosti o konstrukci škály SEAS uvádějí Martin \& Mullis (2012).

Škála SEAS byla konstruována jednak na základě odpovědí ředitelů ve školním dotazníku (těmito daty se dále zabýváme), a paralelně z výpovědí učitelů $\mathrm{v}$ učitelském dotazníku. Poněkud překvapivé jsou významové rozdíly mezi českým, slovenským a anglickým zněním příslušných položek (tabulka 2 výše). K rozdílu v chápání by mohlo dojít u první položky - česky nároky, slovensky a anglicky očekávání učitelů. Pojem expectancy v některých teoriích vyjadřuje hodnotu, kterou má pro jedince určitý cíl (zde prospěch žáka), a souvisela by s tím, zda se učitel „pokusí, nebo nepokusí o dosažení takového cíle" (Křivohlavý, 2004, s. 60). Pak by tato položka měla vyjadřovat nejen to, jaké nároky na žáky učitelé kladou, ale také to, co jsou sami ochotni pro žákův úspěch udělat. Ještě nápadnější je rozdíl u čtvrté položky (zájem rodičů / podpora rodičů) a opět se jedná o míru aktivního jednání vynakládaného pro dosažení cíle. Ostatně u páté položky lze také uvažovat o významovém rozdílu mezi snahou (effort) a touhou, přáním (desire). ${ }^{6}$

Povšimněme si také, že v druhé a třetí položce se český dotazník vztahuje výslovně k určitému konstruktu konkrétní reformy - školnímu vzdělávacímu programu. Vzhledem k tomu, že ŠVP musí být v souladu s Rámcovým vzdělávacím programem pro základní vzdělávání, vycházíme zde $\mathrm{z}$ předpokladu, že uvedené položky by měly do určité míry odrážet to, jak učitelé chápou a implementují celostátní reformu.

Data o podílech škol a průměrných výsledcích škol v závislosti na hodnotách kontextových proměnných, pokud nejsou přímo součástí publikovaných datových souborů, byla vypočtena programem International Data Explorer určeným k analýzám mezinárodních šetření. Statistická významnost rozdílů, kterou uvádím v tabulkách, je $\mathrm{v}$ tomto programu určována nezávislým $t$-testem. Pouze korelační koeficienty a kontingenční tabulky jsem počítal z příslušného národního datového souboru odpovědí ve školním dotazníku bez zohlednění váhy škol.

6 Rakouský dotazník překládá u čtvrté položky elterliche Unterstützung a u páté Wunsch (...) gute Leistungen zu erbringen. 


\section{Výsledky}

$\mathrm{V}$ této části textu nejprve krátce poukážu na hodnoty jednotlivých aspektů SEAS v České republice v porovnání s dalšími zeměmi. Potom se budu zabývat vztahem těchto aspektů $\mathrm{k}$ výsledkům žáků v kognitivních úlohách. Pokud není řečeno jinak, uvádím hodnoty kontextových proměnných ze školního dotazníku TIMSS 2011, tj. podle výpovědí ředitelů škol. Výsledky znamenají průměrné výsledky první populace (u nás žáků 4. ročníků) v matematickém testu téhož šetření.

\subsection{Vnímaná snaha žáků a podpora rodičů}

Jak již bylo řečeno, $v$ mezinárodním průměru a v řadě zemí jednotlivě byla nalezena př́má souvislost mezi matematickým výsledkem a hodnotou SEAS vnímanou řediteli u první i druhé populace (obvykle žáků 4., resp. 8 ročníku). V Česku se však nedaří najít souvislost mezi výsledky žáků a SEAS a dalšími indexy charakterizujícími podmínky ve škole z pohledu ředitelů (Martin et al., 2013). Ani učiteli vnímaný SEAS nemá v České republice statisticky významný vliv na výsledky žáků v matematice. I když z hlediska klasické psychometrie se Cronbachovo alfa u České republiky nevymyká z hodnot pro okolní země (Martin \& Mullis, 2012), problémy s konstruktovou validitou ukazují, že bychom se měli podívat na jednotlivé aspekty SEAS.

Obrázek 2 ukazuje, že z pěti položek, které tvoří index SEAS, se české školy od průměru účastnických zemí nejvíce odlišují v tom, jak jejich ředitelé hodnotí snahu žáků dobře ve škole prospívat (podrobněji viz příloha 1). Nízkým podílem žáků ve školách s vysokou nebo velmi vysokou vnímanou snahou žactva dobře ve škole prospívat se Česko podobá Slovensku a obdobně na tom jsou i další post-socialistické země, Polsko a Mad'arsko (příloha 2). Naproti tomu v Rakousku a Německu se vůbec nevyskytly školy, kde by jejich ředitelé žákům připisovali nízkou nebo velmi nízkou snahu. Současně platí, že v České republice neexistuje souvislost mezi řediteli uváděnou snahou žáků dobře ve škole prospívat a skutečně dosahovanými výsledky v matematice (na úrovni jedinců, tabulka 3). 


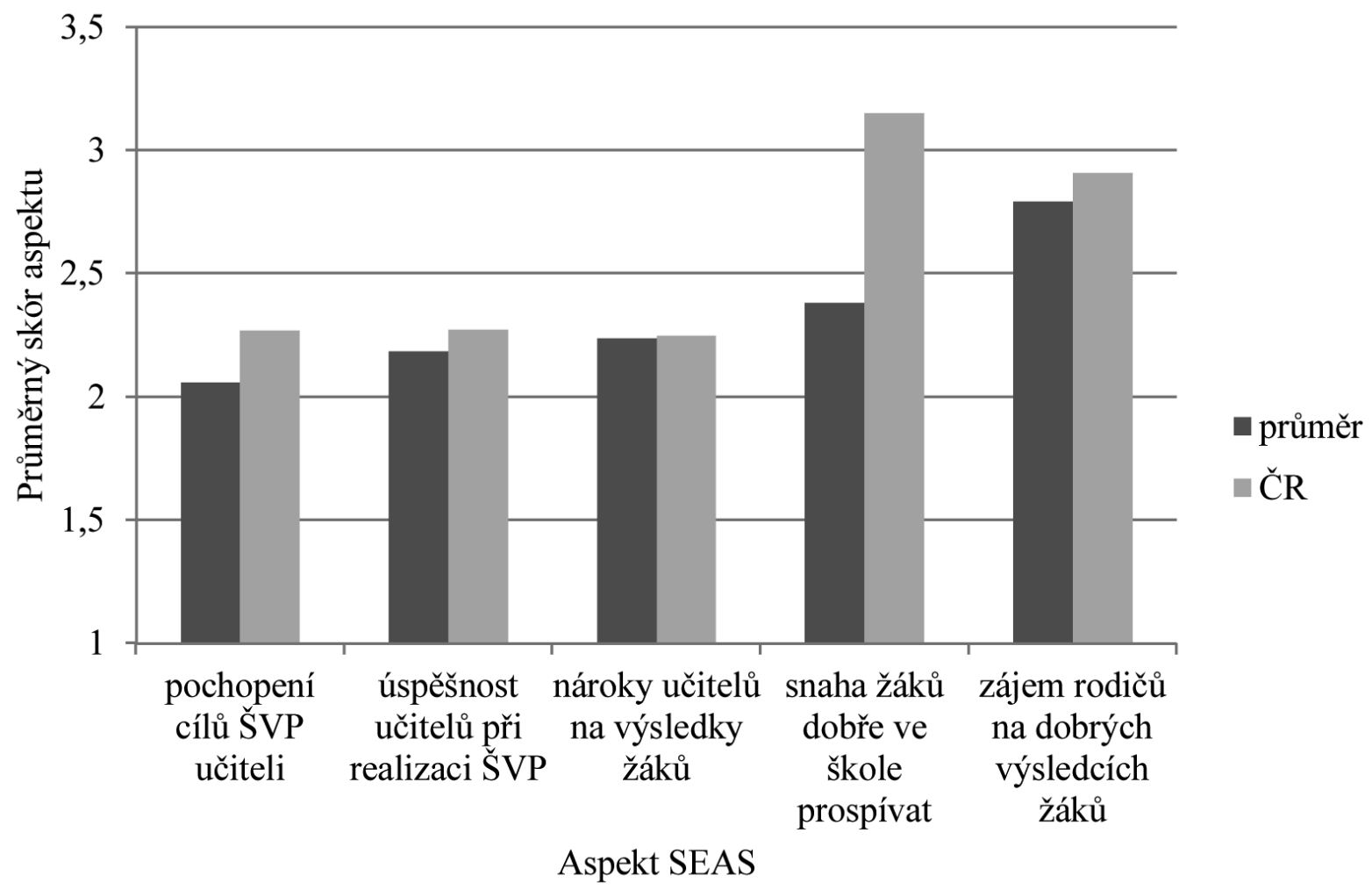

Obrázek 2. Porovnání úrovně jednotlivých aspektů SEAS pro Česko s průměrem účastnických zemí TIMSS 2011 (vyšší skóre znamená nižší hodnocení daného aspektu).

V okolních post-socialistických zemích je také poměrně hodně škol, kde ředitelé uvádějí jen nízkou nebo velmi nízkou podporu, kterou rodiče investují do prospěchu svých dětí. Česká republika se ale v tomto aspektu více podobá Německu či Rakousku, u dané položky mohlo však v českém dotazníku dojít k ovlivnění významu překladem. Ve srovnání s rokem 2007 se v České republice zlepšila hodnota tohoto ukazatele (zjištovaného stejnou otázkou), avšak nezlepšila se vnímaná snaha žáků o dobrý prospěch (Tomášek et al., 2012, s. 26). Zajímavé je porovnání průměrných skórů obou právě diskutovaných aspektů pro země účastnící se šetření (obrázek 3). Ukazuje, že obě položky jsou poměrně výrazně korelované, ale v postsocialistických středoevropských zemích ředitelé (i učitelé) hodnotí snahu žáků celkově hůře než podporu rodičù. 


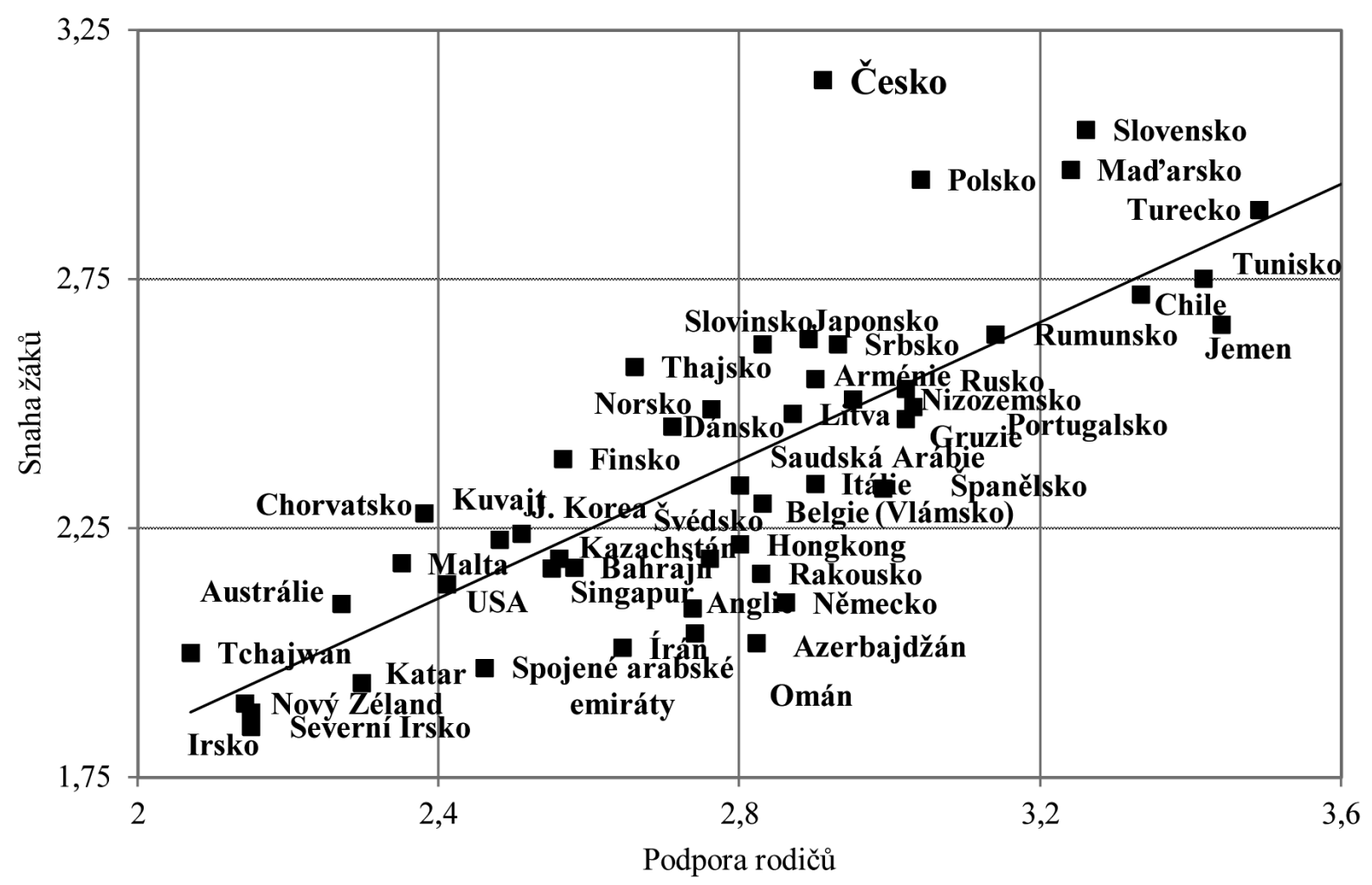

Obrázek 3. Vztah mezi skóry vnímané podpory rodičů a vnímané snahy žáků (data TIMSS 2011).

Tabulka 3

Průměrné rozdíly ve výsledcích matematického testu mezi českými žáky ve školách s různou uváděnou mírou snahy žáků (první číslo je bodový rozdíl na škále TIMSS, jako druhá je uvedena hodnota p)

\begin{tabular}{lccc}
\hline & \multicolumn{3}{c}{ Ředitelem uváděná snaha žáků } \\
\cline { 2 - 4 } střední & vysoká & střední & nízká \\
\multirow{2}{*}{ nízká } & 6 & & \\
& 0,5053 & 11 & \\
velmi nízká & 17 & 0,0607 & 10 \\
& 0,0978 & 0 & 0,1587 \\
\hline
\end{tabular}

Pozn. Zdroj dat: TIMSS 2011. 


\subsection{Vnímaná úspěšnost zavádění ŠVP}

Dvě položky českého školního dotazníku lze (podle mého názoru) interpretovat ve vztahu ke kurikulární reformě minulého desetiletí. Fenomén školních vzdělávacích programů, o kterých český dotazník výslovně hovoří, totiž plošně přinesla teprve tato reforma. $S$ ohledem na mezinárodní kontext však budu mluvit obecněji o školním kurikulu.

$\mathrm{V}$ případě míry porozumění cílům kurikula $\mathrm{v}$ žádné ze sledovaných zemí ředitelé neuváděli velmi nízkou míru porozumění cílům, při implementaci nízkou ani velmi nízkou úspěšnost. (Existují tedy školy, kde je nízká úroveň porozumění cílům, ale alespoň střední úspěšnost jejich implementace, opačně to neplatí.) Proto př́íslušná porovnání v následujících tabulkách nejsou.

Tabulka 4

Vztah mezi řediteli uváděnou mírou pochopení cílů školního kurikula učiteli a výsledky žáků školy (první číslo je rozdíl na škále TIMSS, druhá je uvedena hodnota $p$ )

\begin{tabular}{|c|c|c|c|c|c|c|}
\hline & \multicolumn{6}{|c|}{ Rozdíly výsledků mezi školami s různou úrovní pochopení cílů } \\
\hline & $\begin{array}{c}\text { velmi vysoká / } \\
\text { vysoká }\end{array}$ & $\begin{array}{c}\text { velmi vysoká / } \\
\text { stř̌ední }\end{array}$ & $\begin{array}{c}\text { velmi vysoká / } \\
\text { nízká }\end{array}$ & $\begin{array}{l}\text { vysoká / } \\
\text { stř̌ední }\end{array}$ & $\begin{array}{l}\text { vysoká / } \\
\text { nízká }\end{array}$ & $\begin{array}{l}\text { střední / } \\
\text { nízká }\end{array}$ \\
\hline Rakousko & $\begin{array}{c}-5 \\
0,406\end{array}$ & $\begin{array}{c}-5 \\
0,4202\end{array}$ & $\mathrm{~N}$ & $\begin{array}{c}0 \\
0,9988\end{array}$ & $\mathrm{~N}$ & $\mathrm{~N}$ \\
\hline Česko & $\begin{array}{c}-7 \\
0,6012\end{array}$ & $\begin{array}{c}-8 \\
0,5195\end{array}$ & $\mathrm{~N}$ & $\begin{array}{c}-2 \\
0,7371\end{array}$ & $\mathrm{~N}$ & $\mathrm{~N}$ \\
\hline Německo & $\begin{array}{c}-4 \\
0,5537\end{array}$ & $\begin{array}{c}-2 \\
0,8388\end{array}$ & $\begin{array}{c}-9 \\
0,5763\end{array}$ & $\begin{array}{c}2 \\
0,7082\end{array}$ & $\begin{array}{c}-6 \\
0,726\end{array}$ & $\begin{array}{c}-8 \\
0,6372\end{array}$ \\
\hline Mad’arsko & $\begin{array}{c}6 \\
0,6325\end{array}$ & $\begin{array}{c}13 \\
0,527\end{array}$ & $\begin{array}{c}-7 \\
0,6679\end{array}$ & $\begin{array}{c}7 \\
0,6884\end{array}$ & $\begin{array}{c}-14 \\
0,2887\end{array}$ & $\begin{array}{c}-20 \\
0,3158\end{array}$ \\
\hline Polsko & $\begin{array}{c}9 \\
0,1161\end{array}$ & $\begin{array}{c}19 \\
0,0206^{*}\end{array}$ & $\begin{array}{l}36 \\
0^{* *}\end{array}$ & $\begin{array}{c}10 \\
0,1828\end{array}$ & $\begin{array}{l}27 \\
0^{* *}\end{array}$ & $\begin{array}{c}17 \\
0,0428^{*}\end{array}$ \\
\hline Slovensko & $\begin{array}{c}-3 \\
0,7801\end{array}$ & $\begin{array}{c}22 \\
0,0915\end{array}$ & $\mathrm{~N}$ & $\begin{array}{c}26 \\
0,0045^{* *}\end{array}$ & $\mathrm{~N}$ & $\mathrm{~N}$ \\
\hline
\end{tabular}

Pozn. * znamená $\mathrm{p}<0,05,{ }^{* *}$ znamená $\mathrm{p}<0,01, \mathrm{~N}-$ malý počet škol $\mathrm{v}$ jedné $\mathrm{z}$ porovnávaných kategorií. Zdroj dat: TIMSS 2011.

Tabulka 4 ukazuje, že udávaná míra pochopení cílů školního kurikula nemá, až na Polsko a částečně Slovensko, výrazný vliv na výsledky žáků v matematice. Jinak je tomu s rozdílem mezi výsledky žáků ve školách s vysokým a středním úspěchem při implementaci cílů kurikula (tabulka 5). Rozdíl mezi 
vysokou a střední úspěšností školy při implementaci kurikula se projevil významným rozdílem výsledků žáků v matematice v Rakousku, Německu a zejména Mad’arsku a Polsku, zatímco má nevýznamný efekt na Slovensku a žádný v Česku.

Tabulka 5

Vztah mezi úspěšností implementace cílů školního kurikula učiteli a výsledky žáků školy (první číslo je rozdíl na škále TIMSS, druhá je uvedena hodnota p)

\begin{tabular}{lccc}
\hline & \multicolumn{3}{c}{$\begin{array}{c}\text { Rozdíly výsledků mezi školami } \\
\text { s různou úspěšností implementace }\end{array}$} \\
\cline { 2 - 4 } & velmi vysoká / vysoká & velmi vysoká / střední & vysoká / střední \\
\hline Rakousko & -8 & 14 & 22 \\
Česko & 0,1779 & 0,1662 & $0,0111^{*}$ \\
& -21 & -21 & 0 \\
Německo & 0,2565 & 0,2601 & 0,9894 \\
& 14 & 26 & 12 \\
Mad'arsko & 0,1673 & $0,0148^{*}$ & $0,0191^{*}$ \\
& 15 & 53 & 38 \\
Polsko & 0,2081 & $00^{* *}$ & 15 \\
& 15 & 30 & $0,0049^{* *}$ \\
Slovensko & $0,0135^{*}$ & $0^{* *}$ & 15 \\
& 6 & 21 & 0,0956 \\
\hline
\end{tabular}

Pozn. * znamená $\mathrm{p}<0,05,{ }^{* *}$ znamená $\mathrm{p}<0,01$. Zdroj dat: TIMSS 2011.

V České republice se reforma orientuje na nadpředmětové, vyšší kompetence. Domníval jsem se, že by se porozumění cílům (reformního) kurikula, resp. jeho úspěšná implementace nemusely projevit $\mathrm{v}$ celkovém výsledku žáků v matematice, ale mohly by mít vliv na lepší úroveň „vyšších“ dovedností, tedy schopnosti aplikovat znalosti a usuzovat. Obrázky 4 a 5 ukazují, že tomu tak není. V mezinárodním průměru lepší implementace odpovídá lepším výsledkům pro všechny tři dovednosti. V České republice výsledky škol s řediteli vnímanou velmi vysokou úrovní porozumění cílům ŠVP a vnímanou velmi vysokou úspěšností jeho implementace jsou konzistentně (ale statisticky nevýznamně) horší pro všechny tři dovednosti sledované v šetření TIMSS 2011 (obrázek 5). Podobný výsledek dostáváme i pro všechny oblasti matematického učiva (čísla, geometrie, data). 


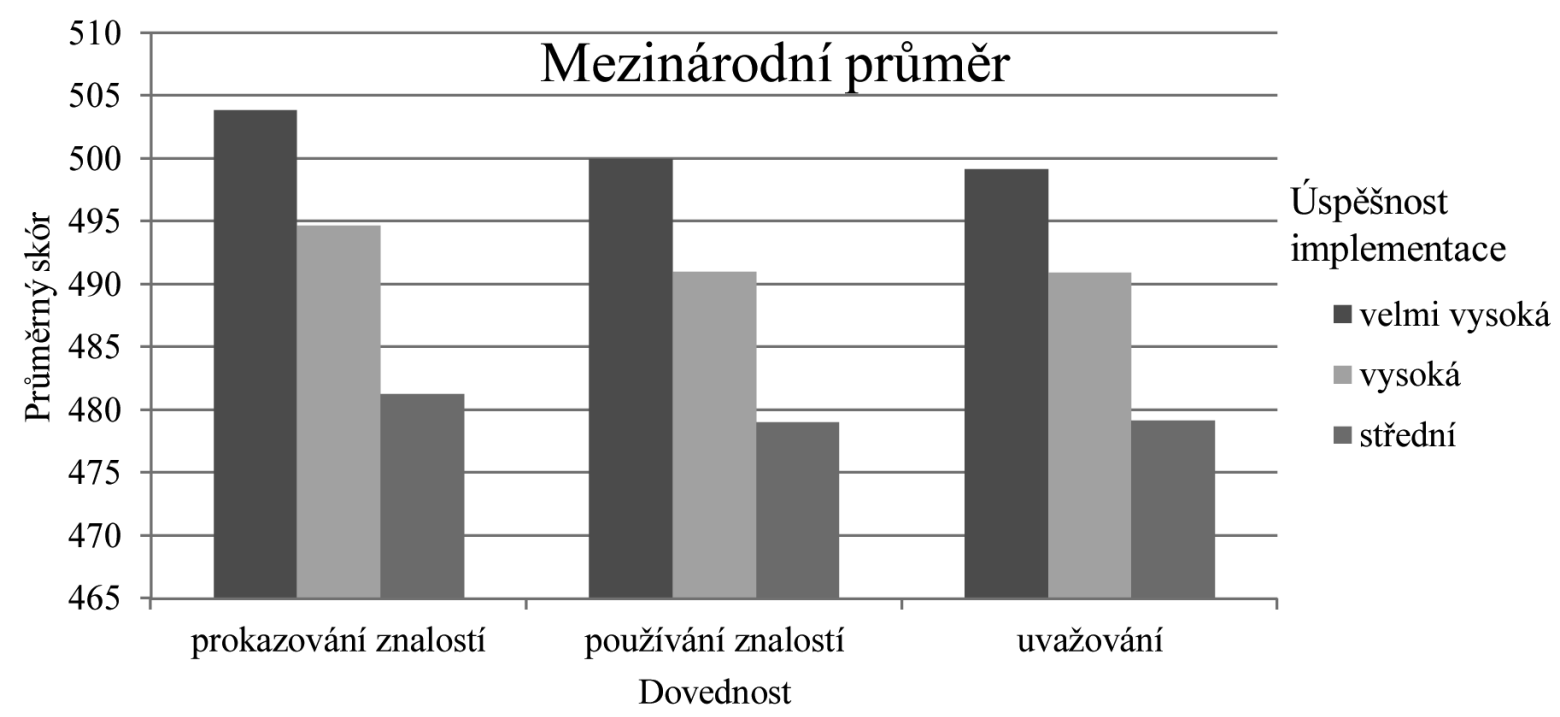

Obrázek 4. Vliv deklarované úspěšnosti implementace školního kurikula na úroveň matematických dovedností (mezinárodní průměry). Pozn. Zdroj dat: TIMSS 2011.

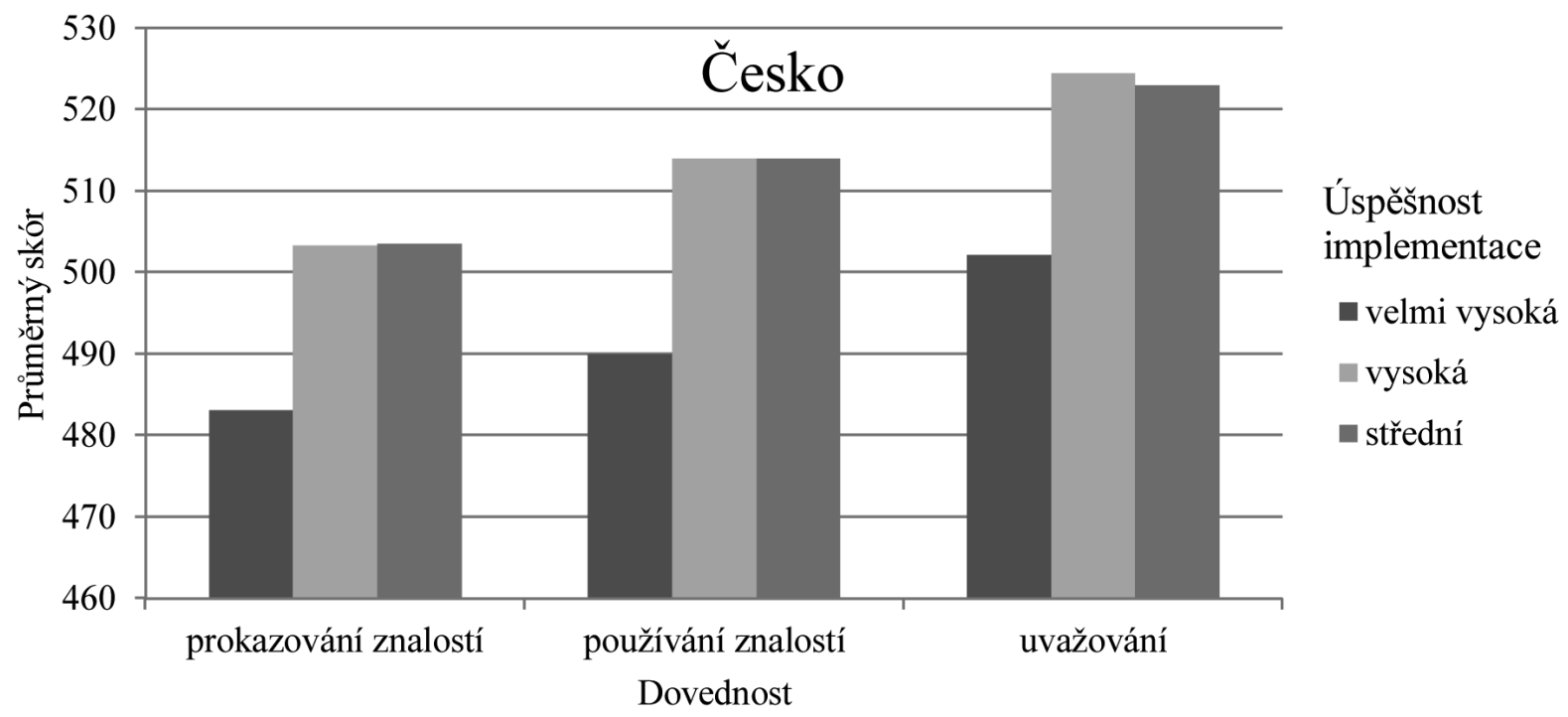

Obrázek 5. Vliv deklarované úspěšnosti implementace školního kurikula na úroveň matematických dovedností (Česká republika). Pozn. Zdroj dat: TIMSS 2011. 
Je samozřejmě nutné uvažovat o tom, zda v českém případě studované proměnné nejsou jen proxy za nějakou jinou charakteristiku školy. Sledoval jsem proto korelace s jinými kontextovými proměnnými. Údaje o socioekonomickém původu žáků (ACBG03A) uvedlo 172 škol (99\%). Testem v kontingenční tabulce byla ověřena na $5 \%$ hladině významnosti nezávislost mezi uváděným počtem žáků s nižším socioekonomickým statusem a oběma proměnnými vztahujícími se k ŠVP (pochopení a implementace). Kromě vzájemné korelace obou otázek vztahujících se k ŠVP $(r=0,54)$ korelovaly tyto otázky nejvíce $\mathrm{s}$ ředitelem uváděnou spokojeností učitelů s jejich prací v konkrétní škole $(r=0,40$ a $r=0,45)$.

\section{Diskuse: SEAS jako zpráva o české reformě?}

Školy v České republice vykazují velmi nízkou hodnotu dưrazu školy na studijní úspěch uváděnou jejich řediteli. Na počátku jsem se domníval, že může jít o vliv reformního diskurzu a zejména národního kurikulárního rámce, který lze označit jako antiakademický, ${ }^{7}$ akcentující praktické cíle a jehož hlavní priority nezahrnovaly zpočátku explicite ani čtenářskou gramotnost, ani matematiku, ani prrírodní vědy (tedy „akademické cíle“). V šetření TIMSS je $d u^{\circ}$ raz školy na studijní/akademický úspěch řazen pod trs proměnných tvořících klima školy. U nás se za hodnoty, které přispívají ke kvalitnímu klimatu školy, považuje spíše orientace na afektivní cíle, široce pojatý osobnostní a sociální rozvoj žáků. Proto jsem předpokládal, že školy budou pod vlivem reformy deklarovat menší tlak na výsledky žáků. Je tomu však naopak, právě v položce zjištujuící deklarovaný akademický tlak se Česká republika mezinárodnímu průměru nejvíc blíží. To znamená, že - alespoň podle vnímání ředitelů důraz na vzdělávací výsledky v českých školách není ani nadprůměrný, ani podprůměrný. Absence neutrálního či afirmativního pedagogického termínu pro kognitivní složku studijních cílů v českém pedagogickém diskurzu tak může spíš odrážet určitou nevyváženost chápání těchto cílů v české pedagogické teorii (nebo reformě) než postojů škol. Vrací se zde téma rozdílnosti

Autoři šetření TIMSS tedy předpokládají, že již na úrovni primární školy může či dokonce má existovat akademický čili studijní důraz. Když však současný český kurikulární rámec (RVP ZV) mluví o základní škole, používá slovo studium pouze ve spojení „další studium“. Studium (lat. úsilí) je tedy z hlediska základní školy nikoli aktuální, ale perspektivní činnost. Jen výjimečně se objevuje doporučení, aby ve škole přátelská a vstřícná atmosféra vybízela žáky ke studiu (Balada et al., 2007, s. 12). Spatřuji zde významný a ne zcela pozitivní vliv Delorsovy zprávy. Určité její čtení může vést k oslabování významu základního vzdělávání ve prospěch celoživotní učení, byt' podle Lee a Friedricha (2011) jde o dezinterpretaci. 
jak jazyků teoretiků, reformátorů, učitelů, ředitelů (Píšová et al., 2011), ale i jejich hodnot či priorit (Dvořák, Starý, \& Urbánek, 2015).

Nízká hodnota SEAS v České republice je tak především důsledkem velmi nízké vnímané snahy žáků dosahovat dobrého prospěchu. To je podle nás velmi závažné zjištění, pokud tento aspekt SEAS chápeme jako míru důvěry mezi klíčovými aktéry školního života v Hoyově (2012) smyslu. Je to bohužel v souladu se zjištěním Dvořáka, Urbánka a Starého (2014), kteří ve své vícepř́padové studii konstatovali malou ochotu škol organizovat systematickou podporu neprospívajícím žákům, protože nevěří ve smysluplnost takového snažení.

Podle amerických výzkumů (Hoy, 2012) spolu důvěra ve snahu žáků a podporu rodičů těsně souvisí zejména na nižších stupních školy a tvoří jeden faktor důvěry v klienty. Také v šetření TIMSS 2011 vykazují agregovaná data pro jednotlivé účastnické státy obdobnou tendenci, avšak skupina středoevropských postsocialistických zemí má odlišné chování s relativně vyšší nedůvěrou v žáky. Stejně tak je zajímavé, že rozdíly ve snaze žáků (uváděné pracovníky školy) se neprojevují ve výsledcích žáků. Tento jev by si zasloužil podrobnější prostudování, může nap̌r. ukazovat na neadekvátní nedůvěru zdejších učitelů k žákům.

Překlad dvou položek v českém kontextovém dotazníku je vztáhl př́imo ke školním vzdělávacím programům jako inovaci plošně zavedené reformou. Na rozdíl od některých sousedních zemí, ředitelem deklarovaná úspěšnost při implementaci kurikula (v českém případě ŠVP) nemá vliv na výsledky žáků. Je to v souladu se zjištěními Rendla a Štecha (2012), kteří v předchozím šetření TIMSS 2007 nenalezli v českém prostředí vztah mezi mírou učitelovy deklarované podpory reformě na jedné straně a kvalitami procesů (posuzovaných žáky) ani efektů výuky.

Konzistentně, ale ne statisticky významně dosahují žáci horších výsledků ve školách deklarujících velmi vysokou míru porozumění cílům ŠVP nebo velmi vysokou úspěšnost při jeho implementaci. Týká se to dokonce i „vyšších" dovedností aplikace učiva a uvažování o něm. K podobnému závěru, že reforma by mohla být dokonce kontraproduktivní, dospěl kvalitativními postupy pro česká gymnázia Janík (2013), obdobně Dvořák a kol. (2015) pro jednu dlouhodobě sledovanou základní školu. Příčinou je formální přijetí reformy a zejména náročnost a neefektivnost povinné tvorby a aktualizace ŠVP, což ředitele a učitele odvádí od otázek kvality výuky a jejích výsledků. 
Formálnímu plnění požadavků reformy napomáhá, že výsledky učení žáků nebyly zjištovány (a mezinárodní šetření jsou zatím jediným zdrojem kvalitnějších dat).

Nabízí se však i jiné vysvětlení: vnímaná potřebnost reformy a snaha implementovat ji mohou být vyšší ve školách, které mají z nějakého důvodu větší problémy se vzděláváním žáků, a tedy dosahují i horších výsledků. Data však neukazují, že by podpora reformy byla vyšší ve školách vzdělávajících žáky z horšího socioekonomického prostředí. Spíše však důrazně deklarovaná podpora (problematické) reformě může být u některých škol dána tendencí alespoň na verbální úrovni vyhovět každému zadání nadřízených orgánů, což nebývá pro kvalitu vzdělávání obvykle př́nosné. Školy úspěšně sledující vlastní rozvojovou agendu mohou být naopak více rezistentní vůči novinkám (Hloušková, 2008, s. 47) i na úrovni verbální, nemají zapotřebí ostentativně podpořit reformu. Netypický vztah mezi konstruktem SEAS a výsledky žáků může být také dán odchylným chováním měřicího nástroje ( $\mathrm{v}$ důsledku volnějšího českého překladu položek školního a učitelského dotazníku). ${ }^{8}$

Samozřejmě, tlak školy na akademický výkon nemusí mít jen př́íznivé důsledky a vysoké požadavky mohou být také nesprávně zaměřeny. I když v literatuře nepanuje shoda, velké studijní nároky mohou vést ke zhoršení psychosociálního klimatu školy a k negativním jevům jako šikana. Bibou-Nakou a kol. (2012) však podotýkají, že př́íčnou v takovém případě nejsou vysoké akademické nároky školy samy o sobě, ale jejich nepřiměřenost možnostem žáků, která vede $\mathrm{k}$ frustraci aktérů. Jako vždy ve výchově, jde tady o rovnováhu. Zdá se, že víc než vysoké požadavky na žáky u nás sociální klima školy může ohrožovat nízká důvěra pedagogických pracovníků k žákům, projevující se mimo jiné nízkou podporou, kterou školy poskytují žákům ze znevýhodněného prostředí (Dvořák et al., 2014).

\section{Závěr}

Studijní čili akademické cíle nadále mají prominentní místo v mnoha zahraničních kurikulech primárního a základního vzdělávání, dokonce lze mluvit o určité jejich renesanci (Dvořák, 2012). V tomto kontextu lze výsledky

\footnotetext{
Pokud bychom nad rámec dat připustili, že vnímaná úspěšnost implementace ŠVP odráží skutečnou míru realizace změn ve výuce, otevíral by se prostor k úvaze, zda reforma skutečně nevede $\mathrm{k}$ horším výsledkům žáků v matematice. Reforma totiž přináší pokles důrazu na matematiku a př́rodní vědy a na tradiční předměty obecně (Dvořák, 2012).
} 
matematické části šetření TIMSS 2011 (Mullis et al., 2012; Tomášek et al., 2012) chápat dvojím způsobem: bud' jako uklidňující signál, že pokles akademických dovedností českých žáků se zastavil, nebo jako negativní zprávu, že se jejich úroveň stále nachází poměrně hluboko pod úrovní dosahovanou našimi žáky v polovině devadesátých let 20. století - zhoršení České republiky oproti výsledkům z roku 1995 stále zůstává největší mezi srovnatelnými zeměmi. Přitom „přetrvává propad zejména ve výsledku lepších žaků, znamená to, že se výrazně snížil podíl českých žaků s výbornými znalostmi z matematiky" (ČŠI, 2013, s. 11). Navíc některé země si dokázaly udržet stabilně dobrou či vynikající úroveň výsledků, nebo dokonce dosáhly ve stejném období významného zlepšení. Zlepšení výsledků českých žáků tak nevede k snížení odstupu od zemí na špičce tabulky, a naopak se snižuje rozdíl mezi našimi výsledky a úrovní rozvíjejících se zemí.

Případný návrat studijních dovedností (nebo základních kompetencí) na výsluní české vzdělávací politiky by neměl být návratem k pojetí češtiny a matematiky známému z předchozích dekád. Podle mého názoru by mělo jít o novou syntézu předchozí tradice a myšlenek kurikulární reformy minulého desetiletí. Taková vyváženější syntéza by mohla mít větší šanci na úspěšnou implementaci ve školách. Akademický optimismus představuje faktor, který může př́znivě ovlivňovat celkové výsledky žáků, a zejména schopnost škol pomáhat znevýhodněným žákům. Proto by si zasloužil větší pozornost výzkumníků i vzdělávací praxe.

\section{Literatura}

Balada, J., Brant, J., Brychnáčová, E., Herink, J., Holasová, T., Horská, V., \& Zahradníková, M. (2007). Rámcový vzdělávací program pro základní vzdělávání. Praha: VÚP.

Bellman, J., \& Weiß, M. (2009). Risiken und Nebenwirkungen neuer Steuerung im Schulsystem. Theoretische Konzeptualisierung und Erklärungsmodelle. Zeitschrift für Pädagogik, 55(2), 286-308.

Bibou-Nakou, I., Tsiantis, J., Assimopoulos, H., Chatzilambou, P., \& Giannakopoulou, D. (2012). School factors related to bullying: A qualitative study of early adolescent students. Social Psychology of Education, 15(2), 125-145.

Bruns, B., Filmer, D., \& Patrinos, H. A. (2011). Making schools work: New evidence on accountability reforms. Washington: World Bank Publications.

Creemers, B. P., \& Kyriakides, L. (2008). The dynamics of educational effectiveness. Abingdon: Routledge.

ČŠI (2013). Vybraná zjištění PIRLS 2011 a TIMSS 2011. Praha: Česká školní inspekce.

de Wolf, I. F., \& Janssens, F. J. (2007). Effects and side effects of inspections and accountability in education: An overview of empirical studies. Oxford Review of Education, 33(3), 379-396. 
Dvořák, D. (2012). Od osnov k vzdělávacím standardům. Praha: Pedagogická fakulta Univerzity Karlovy v Praze.

Dvořák, D., Starý, K., \& Urbánek, P. (2015). Malá škola po pěti letech: Proměny školy v době reformy. Pedagogická orientace, 25(1), 9-31.

Dvořák, D., Urbánek, P., \& Starý, K., (2014). High autonomy and low accountability. Case study of five Czech schools. Pedagogická orientace, 24(6), 919-940.

Eurydice (2009). National testing of pupils in Europe: Objectives, organisation and use of results. Brussels: Education, audiovisual and culture executive agency.

Gavora, P. (2008). Učitel'ovo vnímanie svojej profesijnej zdatnosti (self-efficacy). Prehlad problematiky. Pedagogika, 58(3), 222-235.

Hloušková, L. (2008). Proměna kultury školy v pedagogických diskurzech. Brno: Filozofická fakulta MU.

Hopkins, D., Stringfield, S., Harris, A., Stoll, L., \& Mackay, T. (2014). School and system improvement: A narrative state of the art review. School Effectiveness and School Improvement, 25(2), 257-281.

Hoy, W. (2012). School characteristics that make a difference for the achievement of all students: A 40-year odyssey. Journal of Educational Administration, 50(1), 76-97.

Hoy, W. K., Tarter, C. J., \& Woolfolk Hoy, A. W. (2006). Academic optimism of schools: A force for student achievement. American Educational Research Journal, 43(3), 425-446.

Janík, T. (2013). Od reformy kurikula k produktivní kultuře vyučování a učení. Pedagogická orientace, 23(5), 634-663.

Křivohlavý, J. (2004). Pozitivní psychologie: odpouštění, smiřování, překonávání negativních emocí, radost, naděje. Praha: Portál.

Lee, M., \& Friedrich, T. (2011). Continuously reaffirmed, subtly accommodated, obviously missing and fallaciously critiqued: Ideologies in UNESCO's lifelong learning policy. International Journal of Lifelong Education, 30(2), 151-169.

Mareš, J. (2001). Zvládání školní zátěže u žáků a studentů. In J. Čáp \& J. Mareš (Eds.), Psychologie pro učitele (s. 527-563). Praha: Portál.

Marsh, H. W, Trautwein, U., Lüdtke, O., Köller, O., \& Baumert, J. (2005). Academic self-concept, interest, grades, and standardized test scores: Reciprocal effects models of causal ordering. Child Development, 76(2), 397-416.

Martin, M. O., \& Mullis, I. V. (Eds.). (2012). Methods and procedures in TIMSS and PIRLS 2011. Chestnut Hill: TIMSS \& PIRLS International Study Center, Boston College.

Martin, M. O., Foy, P., Mullis, I. V., \& O'Dwyer, L. M. (2013). Effective schools in reading, mathematics, and science at the fourth grade. In M. O. Martin \& I. V. S. Mullis (Eds.), TIMSS and PIRLS 2011: Relationships among reading, mathematics, and science achievement at the fourth grade-implications for early learning (s. 109-178). Chestnut Hill: TIMSS \& PIRLS International Study Center, Boston College.

Marzano, R. J. (2003). What works in schools: Translating research into action. Alexandria: Association for Supervision and Curriculum Development.

Marzano, R. J., Waters, T., \& McNulty, B. A. (2005). School leadership that works: From research to results. Alexandria: Association for supervision and curriculum development.

Mullis, I. V. S., Martin, M. O., Foy, P., Olson, J., Preuschoff, C., \& Erberber, E. (2008). TIMSS 2007 International mathematics report. Chestnut Hill: TIMSS \& PIRLS International Study Center, Boston College. 
Mullis, I. V. S., Martin, M. O., Foy, P., \& Arora, A. (2012). TIMSS 2011 international results in mathematics. Chestnut Hill: TIMSS \& PIRLS International Study Center, Boston College.

Nilsen, T., \& Gustafsson. J. E. (2014). School emphasis on academic success: Exploring changes in science performance in Norway between 2007 and 2011 employing two-level SEM. Educational Research and Evaluation, 20(4), 308-327.

Píšová, M., Kostková, K., Janík, T., Doulík, P., Hajdušková, L., Knecht, P., ... Vlček, P. (2011). Kurikulární reforma na gymnáziích. Případové studie tvorby kurikula. Praha: VÚP.

Redding, S. (2006). The mega system. Deciding. Learning. Connecting. Lincoln: Academic development institute.

Rendl, M., \& Štech, S. (2012). Should learning (mathematics) at school aim at knowledge or at competences? Orbis scholae, 6(2), 23-40.

Reynolds, D., Sammons, P., De Fraine, B., Van Damme, J., Townsend, T., Teddlie, C., \& Stringfield, S. (2014). Educational effectiveness research (EER): A state-of-the-art review. School Effectiveness and School Improvement, 25(2), 197-230.

Rutkowski, L., von Davier, M., \& Rutkowski, D. (Eds.). (2013). Handbook of international largescale assessment: Background, technical issues, and methods of data analysis. London: CRC Press/Taylor and Francis Group.

Sahlberg, P. (2011). The fourth way of Finland. Journal of Educational Change, 12(2), 173-184.

Shulman, L. S., \& Sherin, M. G. (2004). Fostering communities of teachers as learners: Disciplinary perspectives. Journal of Curriculum Studies, 36(2), 135-140.

Tomášek, V., Kramplová, I., \& Palečková, J. (2012). Národní zpráva TIMSS 2011. Praha: Česká školní inspekce.

UNESCO (2007). Global monitoring report 2008: Education for all by 2015. Will we make it. Paris: UNESCO.

\section{Autor}

RNDr. Dominik Dvořák, Ph.D., Univerzita Karlova v Praze, Pedagogická fakulta, Ústav výzkumu a rozvoje vzdělávání, Myslíkova 7, 11000 Praha, e-mail: dominik.dvorak@pedf.cuni.cz

\section{School emphasis on academic success in TIMSS 2011 as a window on curricular reform in the Czech Republic}

Abstract: TIMSS 2011 study uses new index (SEAS) that is closely related to the concept of academic optimism. This paper describes some causes and ramifications of the low level of SEAS and its components in the Czech Republic. Besides, the SEAS components are used to analyse the relationships between the attitudes of the Czech schools to the curricular reform and achievement of their pupils. Introductory part of the paper describes the concept of academic optimism and the SEAS index in TIMSS 2011. Subsequently, explorative secondary analysis of TIMSS data is performed to explain strikingly low level of SEAS in Czech Republic. The results are discussed in 
the regional perspective. The data on results of Czech $4^{\text {th }}$ grade pupils in TIMSS 2011 mathematics test and school questionnaires were analysed by basic descriptive and inferential statistics methods. The low level of SEAS in the Czech Republic is mainly due to the low perceived pupils' desire to do well in the school. One explanation may be the low trust of teachers and principals to pupils. The analysis also shows paradoxical relationship between the declared support to the reform and pupils' achievement in the Czech schools. The components of the SEAS may be interpreted as a window on the perception and implementation of curricular reform in the Czech Republic.

Keywords: school emphasis on academic success, academic optimism, curricular reform, Czech Republic, TIMSS 2011

\section{Př́loha 1}

\section{Tabulka 1}

Podíly českých žáků ve školách s různou úrovní pěti aspektů indexu SEAS ve srovnání s mezinárodním průměrem (nižší hodnota skóru ukazuje vyšší úroveň aspektu)

\begin{tabular}{llcccccc}
\hline & & \multicolumn{5}{c}{ Podíl žáků ve školách (\%) podle úrovně aspektu } & \multirow{2}{*}{ Skór } \\
\cline { 3 - 6 } & & velmi vysoká & vysoká & střední & nízká & velmi nízká & \\
\hline Pochopení cílů ŠVP & průměr & 21 & 58 & 20 & 2 & 1 & 2,1 \\
učiteli & ČR & 10 & 53 & 37 & & & 2,27 \\
Úsp̌̌šnost učitelů & průměr & 15 & 57 & 27 & 2 & 1 & 2,23 \\
při realizaci ŠVP & ČR & 7 & 59 & 32 & 1 & 0 & 2,25 \\
Nároky učitelů & průměr & 14 & 55 & 28 & 2 & 2 & 2,26 \\
na výsledky žáků & ČR & 11 & 53 & 36 & 0 & 0 & 2,25 \\
Snaha žáků dobře & průměr & 12 & 46 & 38 & 5 & 1 & 2,43 \\
ve škole prospívat & ČR & 0 & 11 & 67 & 18 & 4 & 3,15 \\
Zájem rodičů & průměr & 7 & 29 & 48 & 14 & 4 & 2,85 \\
na dobrých & ČR & 3 & 23 & 56 & 16 & 2 & 2,91 \\
výsledcích & & & & & &
\end{tabular}

Pozn. Zdroj dat: TIMSS 2011. 
Tabulka 2

Podíly českých žáků ve školách s různou úrovní pěti aspektů indexu SEAS ve srovnání s vybranými středoevropskými zeměmi (nižší hodnota skóru ukazuje vyšší úroveň aspektu)

\begin{tabular}{|c|c|c|c|c|c|}
\hline & \multicolumn{5}{|c|}{ Podíl žáků ve školách (\%) podle úrovně aspektu } \\
\hline & velmi vysoká & vysoká & střední & nízká & velmi nízká \\
\hline \multicolumn{6}{|c|}{ Nároky učitelů na výsledky žáků } \\
\hline Česko & 11 & 53 & 36 & - & - \\
\hline Mad’arsko & 3 & 68 & 28 & 1 & - \\
\hline Německo & 5 & 63 & 31 & 2 & - \\
\hline Polsko & 15 & 67 & 18 & - & - \\
\hline Rakousko & 13 & 57 & 30 & - & - \\
\hline Slovensko & 4 & 57 & 37 & 2 & - \\
\hline \multicolumn{6}{|c|}{ Pochopení cílů školního vzdělávacího programu ze strany učitelů } \\
\hline Česko & 10 & 53 & 37 & - & - \\
\hline Mad’arsko & 13 & 71 & 15 & 2 & - \\
\hline Německo & 12 & 68 & 17 & 2 & - \\
\hline Polsko & 27 & 60 & 11 & 2 & - \\
\hline Rakousko & 26 & 65 & 10 & - & - \\
\hline Slovensko & 8 & 67 & 25 & - & - \\
\hline \multicolumn{6}{|c|}{ Úspěšnost učitelů při realizaci školního vzdělávacího programu } \\
\hline Česko & 7 & 59 & 32 & 1 & - \\
\hline Mad’arsko & 7 & 51 & 41 & 1 & - \\
\hline Německo & 5 & 58 & 36 & 1 & - \\
\hline Polsko & 26 & 62 & 12 & - & - \\
\hline Rakousko & 20 & 66 & 15 & - & - \\
\hline Slovensko & 8 & 64 & 28 & - & - \\
\hline \multicolumn{6}{|c|}{ Snaha žáků dobře ve škole prospívat } \\
\hline Česko & - & 11 & 67 & 18 & 4 \\
\hline Mad’arsko & - & 20 & 67 & 11 & 3 \\
\hline Německo & 10 & 69 & 20 & - & - \\
\hline Polsko & 1 & 19 & 66 & 14 & 1 \\
\hline Rakousko & 13 & 58 & 29 & - & - \\
\hline Slovensko & 1 & 9 & 74 & 14 & 1 \\
\hline \multicolumn{6}{|c|}{ Zájem rodičů na dobrých výsledcích žáků } \\
\hline Česko & 3 & 23 & 56 & 16 & 2 \\
\hline Mad’arsko & - & 12 & 58 & 24 & 6 \\
\hline Německo & 3 & 30 & 50 & 14 & 4 \\
\hline Polsko & 3 & 10 & 68 & 18 & 1 \\
\hline Rakousko & 4 & 23 & 59 & 12 & 1 \\
\hline Slovensko & 1 & 6 & 64 & 24 & 5 \\
\hline
\end{tabular}

Pozn. Zdroj dat: TIMSS 2011. 